\title{
Pengembangan Sistem Informasi Penjadwalan Mata Kuliah Berbasis Web Di Fakultas Teknik Universitas Negeri Makassar
}

\author{
Indri Anugrah Ramadhani
}

STKIP Muhammadiyah Sorong

Email: indianugrah18@gmail.com

\begin{abstract}
ABSTRAK
Penelitian ini bertujuan untuk (1) mengetahui tahapan-tahapan pengembangan sistem informasi penjadwalan mata kuliah berbasis web di Fakultas Teknik Universitas Negeri Makassar (2) mengetahui apakah pengembangan sistem informasi penjadwalan mata kuliah berbasis web valid, praktis, dan efektif. Penelitian menggunakan metode pengembangan SDLC (Sistem Development Life Cycle) dengan model pengembangan prototype yang teridiri dari empat tahap yaitu: (a) analisis kebutuhan, (b) perancangan, (c) evaluasi prototype, (d) produk akhir. Sistem informasi penjadwalan mata kuliah yang dikembangkan telah divalidasi oleh dua orang ahli dengan mengalami revisi sehingga didapatkan hasil yang layak digunakan. Uji coba dilakukan dengan melibatkan 35 orang subjek. Setelah dilakukan validasi, hasil penelitian menunjukkan bahwa sistem informasi penjadwalan mata kuliah berbasis web yang dikembangkan dinyatakan valid. Sistem informasi penjadwalan mata kuliah dikatakan praktis karena hasil dari analisis kepraktisan berada pada kategori sangat praktis, dan sistem informasi penjadwalan mata kuliah dikatakan efektif karena hasil dari analisis keefektifan berada pada kategori sangat efektif.
\end{abstract}

Kata Kunci: Sistem Informasi, Penjadwalan, Web

\begin{abstract}
The research aims to discover (1) the development stages of Web-based Course Sceduling Information System in Engineering Faculty of State University of Makassar, (2) wheter the development of Web-based Course Scheduling Information System is valid, practical and effective. The research employed System Development Life Cycle (SDLC) development method with prototype development model which consisted of four stages, namely: (a) needs analysis, (b) deign, (c) prototype evaluation, (d) final product. Course Scheduling Information System which was developed had been validated by two expert with revision, so the result obtained is feasible to be used. The test was conducted by involving 35 subjects. After being validated, the results of the research reveal that Web-based Course Scheduling Information System developed is stated as valid. Course Scheduling Information System is stated as practical because the result of practical analysis indicates that it is in very practical category and Course Scheduling Information System is stated as effective because the result of effectiveness analysis shows that it is in very effective category.
\end{abstract}




\section{Pendahuluan}

Perkembangan ilmu pengetahuan dan teknologi tidak terlepas dari perkembangan kebutuhan manusia. Berbagai kebutuhan mendorong daya pikir manusia untuk mengembangkan teknologi sehingga dapat memberi kemudahan-kemudahan dalam setiap bidang kehidupan, salah satu bidang ilmu pengetahuan dan teknologi yang sedang berkembang dengan pesat adalah sistem teknologi informasi Salah satu teknologi informasi yang berkembang sangat pesat adalah media internet yang dapat diakses dari mana saja, sehingga pemasukan data dapat dilakukan dari mana saja dan dapat dikontrol dari satu tempat sebagai sentral.

Proses perkembangan kebutuhan data dan informasi yang semakin lama berkembang, telah mendorong penanganan data dan informasi yang lebih baik agar setiap unsur tersebut dapat dilaksanakan dengan optimal. Penerapan suatu sistem data dan informasi pada dasarnya tidak terlepas dari penggunaan komputer itu sendiri agar lebih mudah menginputkan data pada sistem. Pesatnya perkembangan IT, khususnya internet, memungkinkan pengembangan layanan informasi yang lebih baik dalam suatu institusi pendidikan. Dilingkungan perguruan tinggi, pemanfaatan IT lainnya yaitu diwujudkan dalam suatu system yang disebut electronic university (e-University). Pengembangan $e$ University bertujuan untuk mendukung penyelenggaraan pendidikan, sehingga perguruan tinggi dapat menyediakan layanan informasi yang lebih baik kepada komunitasnya, baik dalam maupun diluar perguruan tinggi tersebut melalui internet.

Universitas adalah institusi perguruan tinggi yang menyelenggarakan pendidikan akademik juga dapat menyelenggarakan pendidikan professional dalam sejumlah disiplin ilmu pengetahuan, teknologi dan atau kesenian tertentu (Keputusan Menteri Pendidikan Nasional RI, No. 234/U/2000). Universitas merupakan salah satu jenis dari berbagai bidang pendidikan yang ada. Berbagai macam siklus informasi baik seputar kampus, mahasiswa, dosen maupun lingkungan sekitar bergulir setiap harinya. Sistem informasi menjadi hal yang sangat penting demi menunjang kelancaran proses belajar mengajar khususnya bagi suatu universitas. Pada penelitian ini peneliti memilih Fakultas Teknik Universitas Negeri Makassar yang akan menjadi obyek penelitian ternyata belum memaksimalkan komputerisasi dalam pegolahan data nya terutama dalam penjadwalan.

Penjadwalan merupakan kegiatan yang harus dimiliki oleh setiap orang agar dapat membantu dalam melakukan aktivitasnya sehari-hari. Terlebih lagi sebuah instansi atau lembaga yang memiliki agenda-agenda penting yang harus diselesaikan secara teratur dan rapi. Begitu pentingnya penjadwalan ini agar kegiatan dapat berjalan sesuai dengan yang telah direncanakan. Fakultas Teknik merupakan salah satu fakultas di Universitas Negeri Makassar yang telah menerapkan sistem informasi berbasiskan komputer dalam beberapa aktivitasnya. Sistem informasi diharapkan dapat terus digunakan menyeluruh di berbagai aktivitas dalam penyelenggaraan kegiatan yang berhubungan dengan belajar mengajar yang merupakan aktivitas utama, salah satunya adalah dalam hal aktivitas penjadwalan kuliah. Seiring waktu berjalan dibutuhkan sistem baru yang lebih efektif dan efisien, mengingat semakin banyaknya mahasiswa dari tahun ke tahun.

Penjadwalan kegiatan kuliah dalam suatu perguruan tinggi adalah suatu hal yang rumit dan sering mengalami kesulitan, hal ini disebabkan beberapa faktor yang berkaitan yang harus dipertimbangkan antara lain jumlah mata kuliah yang diselenggarakan, jumlah ruangan, jumlah dosen dan jadwal dimana dosen yang bersangkutan tidak bisa mengajar 
yang seringkali menyebabkan munculnya masalah penjadwalan mata kuliah. Sistem penjadwalan mata kuliah ini nantinya memiliki hak akses yang berbeda sehingga sistem penjadwalan mata kuliah ini memakai sistem multiuser. Sistem terdiri dari bagian Admin, Dosen dan Mahasiswa. Adapun komponen-komponen yang akan dimasukkan pada sistem penjadwalan mata kuliah ini yaitu: Data Dosen, Mata Kuliah, Ruangan, Waktu/Jam, Laporan Jadwal Mengajar.

Penjadwalan kuliah di Universitas Negeri Makassar (UNM) sebenarnya sudah ada, bisa dilihat pada sistem informasi akademik kampus, hanya saja sistem tersebut masih belum maksimal, masih ada beberapa jadwal yang belum terisi yaitu untuk ruangan, hari, dan jam kuliah, juga dalam hal pengaksesan terkadang lambat karena padatnya mahasiswa yang login secara bersamaan. Pada fakultas teknik sistem penjadwalan kuliah masih dibuat manual, adapaun hasil survei yang dilakukan pada tanggal 6 Maret 2017 oleh salah satu staff di jurusan elektronika fakultas teknik mengatakan bahwa penjadwalan kuliah masih dibuat dengan menggunakan Microsoft Exel, penyebaran jadwal kuliah dilakukan dengan menempelnya di papan pengumuman jurusan. Pada jurusan mesin peneliti juga melakukan wawancara pada salah satu staffnya yang mengatakan bahwa penjadwalan mata kuliah dilakukan dengan proses manual dimana jadwal dibuat dalam Microsoft Exel. Selain itu, pada jurusan otomotif dan sipil juga masih menggunakan sistem manual, hanya pada jurusan elektro prodi pendidikan teknik informatika dan komputer yang telah menggunakan penjadwalan kuliah berbasis online.

Permasalahan yang dihadapi oleh Fakultas Teknik Universitas Negeri Makassar dalam hal penjadwalan mata kuliah untuk mengatasinya diperlukan sistem informasi agar proses perkuliahan berjalan sesuai dengan yang diinginkan. Berdasarkan latar belakang di atas maka peneliti mengambil judul "Pengembangan Sistem Informasi Penjadwalan Mata Kuliah Berbasis Web di Fakultas Teknik Universitas Negeri Makassar”.

\section{Kajian teori}

\section{Pengertian Sistem}

Pengertian sistem itu berbeda-beda, tetapi meskipun pengertian sistem itu bervariasi maka semua sistem pada bidang tersebut mempunyai beberapa persyaratan umum, yaitu sistem harus mempunyai lingkungan, elemen, interaksi antar element dan lingkungannya, dan yang terpenting adalah sistem harus mempunyai tujuan yang akan dicapai. Sistem adalah suatu jaringan kerja dari prosedur prosedur yang saling berhubungan, berkumpul bersama-sama untuk melakukan suatu kegiatan atau untuk menyelesaikan suatu sasaran yang tertentu (Jogiyanto, 2005). Selain itu, sistem juga diartikan sekelompok unsur yang erat hubungannya satu dengan yang lain, yang berfungsi bersama-sama untuk mencapai tujuan tertentu (Tata, 2004).

Sistem adalah setiap kesatuan secara konseptual atau fisik yang terdiri dari bagianbagian dalam keadaan saling tergantung satu sama lainnya (Paryati, 2007). Sedangkan menurut James (2009) sistem merupakan prosedur logis dan rasional untuk merancang suatu rangkaian komponen yang berhubungan satu dengan yang lainnya dengan maksud untuk berfungsi sebagai suatu kesatuan dalam usaha mencapai suatu tujuan yang telah ditentukan.

Sistem dapat juga didefenisikan dengan pendekatan prosedur dan dengan pendekatan komponen. Dengan pendekatan prosedur, sistem dapat didefenisikan sebagai kumpulan dari prosedur-prosedur yang mempunyai tujuan tertentu. Dengan pendekatan komponen, sistem 
dapat didefenisikan sebagai kumpulan dari komponen yang saling berhubungan satu dengan yang lainnya membentuk satu kesatuan untuk mencapai tujuan tertentu (Jogiyanto, 2009).

Beberapa definisi tentang sistem diatas, maka dapat ditarik suatu kesimpulan bahwa sistem merupakan sekumpulan prosedur atau tahapan yang terdiri atas komponen atau elemen yang saling berhubungan untuk mencapai tujuan tertentu.

\section{Pengertian Informasi}

Menurut Jogiyanto (2005), informasi adalah data yang diolah menjadi bentuk yang lebih berguna dan lebih berarti bagi yang menerimanya. Sedangkan menurut Davis dalam Kadir (2003), informasi adalah data yang telah diolah menjadi sebuah bentuk yang berarti bagi penerimanya dan bermanfaat bagi pengambilan keputusan saat ini atau saat mendatang. Sumber dari informasi adalah data. Menurut Phil (2006), data adalah kumpulan objek-objek beserta atributnya yang menunjukkan karakteristik dari objek tersebut.

Informasi adalah data yang telah diklasifikasikan atau diolah atau diinterpretasikan untuk digunakan dalam proses pengambilan keputusan. Sistem pengolahan informasi akan memperoleh data menjadi informasi atau mengolah data dari bentuk tak berguna menjadi berguna bagi yang menerimanya (Tata, 2004).

Beberapa kesimpulan di atas, maka penulis menyimpulkan bahwa informasi itu adalah suatu keterangan yang diperoleh dari data-data yang dihasilkan dari sumber-sumber yang dapat menambah pengetahuan seseorang.

\section{Sistem Informasi}

Menurut Wiranto (2004), sistem informasi merupakan sistem yang berisi jaringan SPD (Sistem Pengolahan Data), yang dilengkapi dengan kanal-kanal komunikasi yang digunakan dalam sistem organisasi data. Sebuah rangkaian prosedur formal dimana data dikumpulkan, diproses menjadi informasi, dan didistribusikan kepada pemakai (James, 2001). Sedangkan menurut Jogiyanto (2009), sistem informasi merupakan suatu sistem yang tujuannya menghasilkan informasi.

Menurut Alter (2002), an information system is a software system to capture, transmit, store, retrieve, manipulate, or display information, thereby supporting people, organizations, or other software system. (Sistem informasi adalah suatu sistem perangkat lunak untuk menangkap, mentransmisikan, menyimpan, mengambil, memanipulasi, atau menampilkan informasi, sehingga mendukung orang, organisasi, atau sistem perangkat lunak lain).

Menurut Burch dan Grudnitski, kualitas informasi ditentukan oleh tiga faktor, yaitu : (a) Relevansi, (b) Tepat waktu, dan (c), Akurasi. Akurasi berarti bahwa informasi bebas dari kesalahan. Relevansi berarti bahwa informasi benar-benar berguna bagi suatu tindakan keputusan yang dilakukan oleh seseorang. Tepat waktu berarti bahwa informasi datang pada saat dibutuhkan sehingga bermanfaat untuk pengambilan keputusan. Untuk mempermudah bagi para pekerja di suatu organisasi dalam memperoleh informasi, teknologi informasi biasa dilibatkan. Secara lebih khusus, organisasi umumnya menerapkan sistem informasi.

\section{Penjadwalan}

Penjadwalan adalah pengaturan waktu dari suatu kegiatan operasi penjadwalan mencakup kegiatan mengalokasikan fasilitas, peralatan ataupun tenaga kerja bagi suatu kegiatan operasi dan menentukan urutan pelaksanaan kegiatan operasi. Dalam hierarki pengambilan keputusan, penjadawalan merupakan langkah terakhir sebelum dimulainya 
operasi (Eddy, 2001). Selain itu, penjadwalan juga diartikan sebagai kumpulan kebijaksanaan dan mekanisme di setiap operasi yang berkaitan dengan urutan kerja yang dilakukan sistem komputer. Penjadwalan memutuskan peoses yang harus berjalan dan kapan dan selama berapa lama proses itu berjalan (Bambang, 1997).

Menurut Chambers (1995) menyatakan bahwa jadwal didefinisikan sebagai sesuatu yang menjelaskan di mana dan kapan orang-orang dan sumber daya berada pada suatu waktu. Aktifitas penjadwalan pada dasarnya dapat dibedakan menjadi lima tingkatan, yaitu: (a) Long-range planning (waktu 2 sampai 5 tahun), (b) Middle-range planning (waktu 1 sampai 2 tahun), (c) Short-range planning (waktu 3 sampai 6 bulan), (d) Penjadwalan (waktu 2 sampai 6 minggu), dan (e) Penjadwalan reaktif atau control (waktu 1 sampai 3 hari. (Wahyuni, 2009).

\section{Pendidikan Kejuruan}

Pendidikan kejuruan pada dasarnya adalah pendidikan untuk menumbuhkan atau menggerakkan kegiatan ekonomi, karena pendidikan kejuruan dirancang untuk memenuhi kebutuhan pasar kerja dan jelaslah hal ini akan memberikan sumbangan positif bagi dunia kerja produktif yang menghasilkan barang dan komoditi yang mempunyai nilai ekonomi, selanjutnya secara kolektif tenaga kerja produktif yang mampu memproduksi barang yang bernilai secara akumulatif akan menggerakan roda perekonomian dan hal ini berpengaruh terhadap pertumbuhan ekonomi secara nasional (Jalinus, 2011). Pendidikan Vokasional atau Vocational Education (VE) adalah pendidikan untuk dunia kerja (Education for Vocation atau Education for Occupations). Pendidikan Vokasional adalah pendidikan untuk mengembangkan ke-vokasia-an seseorang sehingga memiliki kapasitas atau kapabilitas ditugasi atau diberi perintah untuk melakukan pekerjaan atau jabatan tertentu (Sudira, 2016).

Prosser adalah seorang praktisi dan akademisi Amerika Serikat yang sering dianggap sebagai bapak pendidikan kejuruan, terutama di Amerika (Tamrin, 2013). Di kalangan akademisi pendidikan vokasi dan kejuruan di Indonesia, Prosser cukup dikenal sebagai penyusun 16 prinsip pendidikan kejuruan atau sering juga disebut sebagai 16 Dalil Prosser. Menurut Charles Prosser (1925), prinsip-prinsip pendidikan kejuruan dapat dikemukakan sebagai berikut:

1. Pendidikan kejuruan akan efisien jika lingkungan dimana siswa dilatih merupakan replika lingkungan dimana nanti ia akan bekerja.

2. Pendidikan kejuruan yang efektif hanya dapat diberikan dimana tugas-tugas latihan dilakukan dengan cara, alat dan mesin yang sama seperti yang ditetapkan di tempat kerja.

3. Pendidikan kejuruan akan efektif jika dia melatih seseorang dalam kebiasaan berpikir dan bekerja seperti yang diperlukan dalam pekerjaan itu sendiri.

4. Pendidikan kejuruan akan efektif jika dia dapat memampukan setiap individu memodali minatnya, pengetahuannya dan keterampilannya pada tingkat yang paling tinggi.

5. Pendidikan kejuruan efektif untuk setiap profesi, jabatan atau pekerjaan hanya dapat diberikan kepada seseorang yang memerlukannya, yang menginginkannya dan yang dapat untung darinya.

6. Pendidikan kejuruan akan efektif jika pengalaman latihan untuk membentuk kebiasaan kerja dan kebiasaan berfikir yang benar diulangkan sehingga pas seperti yang diperlukan dalam pekerjaan nantinya. 
7. Pendidikan kejuruan akan efektif jika gurunya telah mempunyai pengalaman yang sukses dalam penerapan keterampilan dan pengetahuan pada operasi dan proses kerja yang akan dilakukan.

8. Pada setiap jabatan ada kemampuan minimum yang harus dipunyai oleh seseorang agar dia tetap dapat bekerja pada jabatan tersebut.

9. Pendidikan kejuruan harus memperhatikan permintaan pasar (memperhatikan tandatanda pasar kerja).

10. Proses pembinaan yang efektif pada siswa akan tercapai jika pelatihan diberikan pada pekerjaan yang nyata (pengalaman sarat nilai).

11. Sumber yang dapat dipercaya untuk mengetahui isi pelatihan pada suatu okupasi tertentu adalah dari pengalaman para ahli pada okupasi tersebut.

12. Setiap okupasi mempunyai ciri-ciri isi (body of content) yang berbeda-beda satu dengan yang lainnya.

13. Pendidikan kejuruan akan merupakan layanan sosial yang efisien jika sesuai dengan kebutuhan seseorang yang memang memerlukan dan memang paling efektif jika dilakukan lewat pengajaran kejuruan.

14. Pendidikan kejuruan akan efisien jika metode pengajaran yang digunakan dan hubungan pribadi dengan peserta didik mempertimbangkan sifat-sifat peserta didik tersebut.

15. Administrasi pendidikan kejuruan akan efisien jika dia luwes dan mengalir daripada kaku dan terstandar.

16. Pendidikan kejuruan memerlukan biaya tertentu dan jika tidak terpenuhi maka pendidikan kejuruan tidak boleh dipaksakan beroperasi. (Wardiman, 1998:38).

Berdasarkan uraian 16 dalil Charles Prosser peneliti mengambil teori ke 15: Administrasi pendidikan kejuruan akan efisien jika dia luwes dan mengalir dari pada kaku dan terstandar. Menjadi salah satu perubahan lingkungan yang sangat mempengaruhi dunia pendidikan adalah hadirnya teknologi informasi, teknologi informasi telah menjadi fasilitas utama bagi kegiatan sektor lingkungan menejemen pendidikan. Dimana sistem informasi mampu mengatur secara terstruktur administrasi yang dibutuhkan dalam kehidupan seharihari di lingkungan sekolah agar lebih efektif, efisien dan praktis dalam pelaksanaanya.

\section{Web}

Menurut Yuhefizar, web adalah suatu metode untuk menampilkan informasi di internet baik berupa teks, gambar, suara, maupun video yang interaktif dan mempunyai kelebihan untuk menghubungkan (link) satu dokumen dengan dokumen lainnya (hypertext) yang dapat diakses melalui sebuah browser. Sedangkan menurut Boone (Thomson), web adalah koleksi sumber informasi kaya grafis yang saling berhubungan satu sama lain dalam internet yang lebih besar.

World Wide Web (WWW), lebih dikenal dengan web merupakan salah satu layanan yang didapat oleh pemakai komputer yang terhubung ke internet. Web atau website adalah ruang informasi dalam internet, dengan menggunakan teknologi hyperteks, pemakai dituntun untuk menemukan informasi dengan mengikuti link yang disediakan dalam dokumen web yang ditampilkan dalam browser web (Sidik, 2009).

\section{Syarat-syarat web}

1) Web yang valid meliputi indikator:

a) Proses pengaksesan berhasil, seperti login, melakukan pencarian, logout, dll. 
b) Semua konten dapat ditampilkan dengan baik.

c) Semua fitur yang disediakan berjalan dengan baik

2) Web yang praktis meliputi indikator (Gupta, 2007):

a) Kemudahan dalam penggunaan

b) Mempersingkat waktu penyampaian informasi.

c) Dapat menyimpan dan memperoleh informasi yang cepat, mudah dan akurat.

3) Web yang efektif meliputi indikator (DeLone, 1992) :

a) Kualitas sistem : kemudahan dipelajari, kesesuaian, kehandalan sistem, waktu respons, serta kegunaan menu-menu dan fungsi-fungsi sistem.

b) Kualitas informasi : relevan, kepahaman, kelengkapan, keamanan, dan ketepatwaktuan.

c) Kepuasan peemakai : kepuasan terhadap perangkat sistem, sistem dapat mengerjakan dengan mudah apa yang diinginkan sistem.

\section{Hypertext Preprocessor (PHP)/MySql}

PHP merupakan kepanjangan dari Hypertext Preprocessor adalah suatu bahasa pemrograman berbasiskan kode-kode (script) yang digunakan untuk mengolah suatu data dan mengirimkannya kembali ke web browser menjadi kode HTML (Oktavian, 2010). PHP juga merupakan singkatan dari Hypertext Preprocessor yang merupakan bahasa berbentuk skrip yang ditempatkan dalam server dan diproses di server. Hasilnyalah yang dikirmkan ke klien, tempat pemakai menggunakan browser (Kadir, 2008).

PHP adalah singkatan dari Hypertext Preprocessor yang digunakan sebagai bahasa script server-side dalam mengembangkan web yang disisipkan pada dokumen HTML (Peranginangin. 2006). Penggunaan PHP memunkinkan web dapat dibuat dinamis sehingga maintenance situs web tersebut menjadi lebih mudah dan efisien. Sintaks program/script HP ditulis dalam apitan tanda Khusus PHP. Ada empat macam pasangan tag PHP yang dapat digunakan untuk menandai blok script PHP.

Menurut Nugroho (2009), MySQL adalah sebuah program database server yang mampu menerima dan mengirimkan datanya dengan sangat cepat, multi user, serta menggunakan perintah standar SQL. MySQL merupakan FreeSoftware dibawah lisensi GNU/GPL (General Public License). MySql menggunakan suatu format standar SQL (Structure query language) yakni bahasa yang berisi perintah-perintah untuk memanipulasi data base, mulai dari melakukan perintah select untuk menampilkan isi data base, menginsert atau menambahkan isi kedalam data base, men-delete atau menghapus isi data base dan mengedit data base. Dalam SQL terdapat beberapa elemen komponen yang penting, pertama DDL (Data Definition Language) adalah statement yang berhubungan dengan pembuatan objek dan pengolahan strukturnya.

\section{Xampp}

Menurut Jogiyanto (2005), Xampp adalah perangkat lunak bebas, yang mendukung banyak sistem operasi, merupakan kompilasi dari beberapa program. Fungsinya adalah sebagai server yang berdiri sendiri (localhost), yang terdiri atas program Apache HTTP Server, MySQL database, dan penerjemah bahasa yang ditulis dengan bahasa pemrograman PHP dan Perl. Nama XAMPP merupakan singkatan dari X (empat sistem operasi apapun), Apache, MySQL, PHP dan Perl. Program ini tersedia dalam GNU General Public License dan bebas, merupakan web server yang mudah digunakan yang dapat melayani tampilan halaman web yang dinamis. 
XAMPP merupakan paket php berbassis open source yang dikembangkan oleh sebuah komunitas Open Source. Dengan menggunakan XAMPP tidak perlu lagi melakukan penginstalan program yang lain karena semua kebutuhan telah disediakan oleh XAMPP. Beberapa paket yang telah disediakan adalah Apache, MySql, PHP, Filezila, dan Phpmyadmin (Nugroho, 2011). Sedangkan menurut Wahana (2009), XAMPP adalah salah satu paket instalasi apache, PHP, dan MySQL secara instant yang dapat digunakan untuk membantu proses instalasi produk.

\section{Data Flow Diagram (DFD)}

Data Flow Diagram (DFD) adalah Diagram yang menggunakan notasi simbol untuk menggambarkan arus data system (Jogiyanto, 2005). DFD adalah desain logika dari sebuah sistem yang menggambarkan secara rinci urut-urutan langkah dari masing-masing proses yang digambarkan dalam diagram arus data. Simbol-simbol yang dipakai dalam DFD dapat dilihat pada Tabel 2.1 (Sutanta, 2003). DFD sering digunakan untuk menggambarkan suatu sistem yang telah ada atau sistem baru yang akan dikembangkan secara logika tanpa mempertimbangkan lingkungan fisik dimana data tersebut disimpan. DFD menggambarkan arus data didalam sistem dengan terstruktur dan jelas dan dapat memudahkan pemakai yang kurang menguasai bidang komputer untuk mengerti sistem yang akan dikerjakan atau yang akan dikembangkan.

Data Flow Diagram (DFD) terdapat 3 level, yaitu (Jogiyanto, 2005):

(a) Diagram Konteks: menggambarkan satu lingkaran besar yang dapat mewakili seluruh proses yang terdapat di dalam suatu sistem. Merupakan tingkatan tertinggi dalam DFD dan biasanya diberi nomor 0 (nol). Semua entitas eksternal yang ditunjukkan pada diagram konteks berikut aliran-aliran data utama menuju dan dari sistem. Diagram ini sama sekali tidak memuat penyimpanan data dan tampak sederhana untuk diciptakan.

(b) Diagram Nol (diagram level-1): merupakan satu lingkaran besar yang mewakili lingkaranlingkaran kecil yang ada di dalamnya. Merupakan pemecahan dari diagram Konteks ke diagram Nol. di dalam diagram ini memuat penyimpanan data.

(c) Diagram Rinci: merupakan diagram yang menguraikan proses apa yang ada dalam diagram Nol.

\section{Metode Penelitian dan Pengembangan/ Research and Development (R\&D)}

Menurut Sugiyono (2015), Metode penelitian dan pengembangan dapat diartikan sebagai cara ilmiah untuk meneliti, merancang, memproduksi dan menguji validitas produk yang telah dihasilkan. Berdasarkan pengertian tersebut, kegiatan penelitian dan pengembangan dapat disingkat menjadi 4P (Penelitian, Perancangan, Produksi, dan Pengujian).

Design and Development Research adalah, "the systematic study of design, development and evaluation processes with the aim of establishing an empirical basis for the creation of instructional and noninstructional product and tool and new or enhanced model that govern their development". Perancangan dan penelitian pengembangan adalah kajian yang sistematis tentang bagaimana membuat rancangan suatu produk, mengembangkan/ memproduksi rancangan tersebut, dan mengevaluasi kinerja produk tersebut, dengan tujuan dapat diperoleh data yang empiris yang dapat digunakan sebagai dasar untuk membuat produk, alat-alat dan model yang dapat digunakan dalam pembelajaran atau nonpembelajaran (Richey and Kelin, 2010). 


\section{Model Prototipe}

Model prototipe dapat digunakan untuk menyambungkan ketidakpahaman pelanggan mengenai hal teknis dan memperjelas spesifikasi kebutuhan yang diinginkan pelanggan kepada pengembang perangkat lunak. Model prototipe (prototyping model) dimulai dari mengumpulkan kebutuhan pelanggan terhadap perangkat lunak yang akan dibuat. Lalu dibuatlah program prototipe agar pelanggan lebih terbayang dengan apa yang sebenarnya diinginkan. Program prototype biasanya merupakan program yang belum jadi. Program ini biasanya menyediakan tampilan dengan simulasi alur perangkat lunak sehingga tampak seperti perangkat lunak yang sudah jadi.

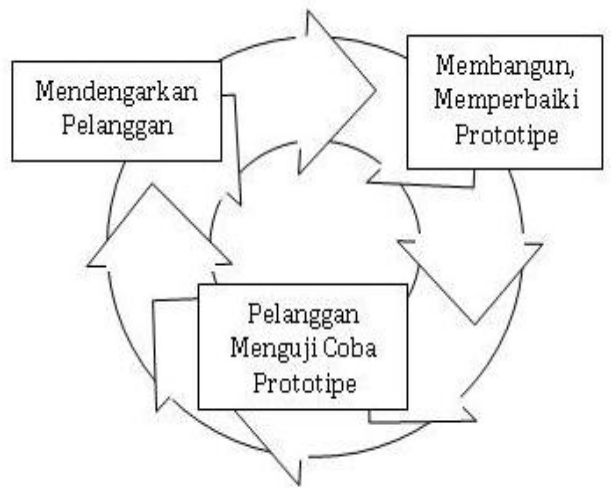

Gambar 2.6

Ilustrasi Model Prototipe (Rosa, 2013)

Model prototype juga memiliki kelemahan yaitu, pelanggan dapat sering mengubahubah atau menambah spesifikasi kebutuhan karena menganggap aplikasi sudah dengan cepat dikembangkan, karena adanya iterasi ini dapat menyebabkan pengembang banyak mengalah deengan pelanggan karena perubahan atau penambahan spesifikasi kebutuhan perangkat lunak.

\section{Metode penelitian}

\section{Jenis Penelitian}

Jenis penelitian yang digunakan adalah jenis penelitian dan pengembangan (research and development/ R\&D). Penelitian dan Pengembangan atau Research and Development (R\&D) adalah rangkaian proses atau langkah-langkah dalam rangka mengembangkan suatu produk baru atau menyempurnakan produk yang telah ada agar dapat dipertanggung jawabkan. Pengembangan adalah proses penerjemahan spesifikasi desain ke dalam bentuk fisik yang berkaitan dengan desain belajar sistematik, pengembangan dan evaluasi memproses dengan maksud menetapkan dasar empiris untuk mengkreasikan produk pembelajaran dan nonpembelajaran yang baru atau model peningkatan pengembangan yang sudah ada. (Richey, 2007).

Penelitian pengembangan ini, peneliti akan mengembangkan dan memvalidasi sebuah sistem informasi penjadwalan mata kuliah pada Fakultas Teknik UNM (Universitas Negeri Makassar), pengembangan sistem akan dilakukan berdasarkan prosedur pengembangan yang digunakan, sehingga produk yang dikembangkan layak dimanfaatkan dalam kegiatan perkuliahan. 


\section{Teknik Analisis Data}

Teknik analisis data dalam penelitian ini menggunakan statistik deskriptif. Statistik deskriptif adalah statistik yang digunakan untuk menganalisis data dengan cara mendeskripsikan atau menggambarkan data yang telah terkumpul sebagaimana adanya tanpa bermaksud membuat kesimpulan yang berlaku untuk umum atau generalisasi (Sugiyono, 2014). Kemudian statistik deskriptif yang digunakan dalam penelitian ini adalah penyajian data dengan tabel, perhitungan rata-rata, standar deviasi dan persentase.

1. Validitas

Kategori validitas setiap aspek atau keseluruhan aspek yang dinilai ditetapkan berdasarkan kriteria pengkategorian sebagai berikut:

Tabel 3.1 Pedoman penskoran kevalidan

\begin{tabular}{ccl}
\hline No & Interval & Kategori \\
\hline 1 & $>3,25 \mathrm{~s} / \mathrm{d} 4,0$ & Sangat valid \\
2 & $>2,25 \mathrm{~s} / \mathrm{d} 3,25$ & Valid \\
3 & $>1,75 \mathrm{~s} / \mathrm{d} 2,25$ & Krng valid \\
4 & $1,0 \mathrm{~s} / \mathrm{d} 1,75$ & Tidak valid \\
\hline
\end{tabular}

2. Praktis

Untuk menganalisis kepraktisan penggunaan sistem informasi penjadwalan kuliah menggunakan pengkategorian sebagai berikut:

Tabel 3.2 Pedoman penskoran kepraktisan

\begin{tabular}{ccl}
\hline No & Interval & \multicolumn{1}{c}{ Kategori } \\
\hline 1 & $>3,25 \mathrm{~s} / \mathrm{d} 4,0$ & Sangt praktis \\
2 & $>2,25 \mathrm{~s} / \mathrm{d} 3,25$ & Praktis \\
3 & $>1,75 \mathrm{~s} / \mathrm{d} 2,25$ & Kurng praktis \\
4 & $1,0 \mathrm{~s} / \mathrm{d} \mathrm{1,75}$ & Tidak praktis \\
\hline
\end{tabular}

Sumber: Widoyoko (2016).

\section{Efektifitas}

Untuk menganalisis efektifitas penggunaan sistem informasi penjadwalan kuliah menggunakan pengkategorian sebagai berikut:

Tabel 3.3 Pedoman penskoran keefektifan 


\begin{tabular}{ccl}
\hline No & Interval & \multicolumn{1}{c}{ Kategori } \\
\hline 1 & $>3,25 \mathrm{~s} / \mathrm{d} 4,0$ & Sangat efektif \\
2 & $>2,25 \mathrm{~s} / \mathrm{d} 3,25$ & Efektif \\
3 & $>1,75 \mathrm{~s} / \mathrm{d} 2,25$ & Krng efektif \\
4 & $1,0 \mathrm{~s} / \mathrm{d} 1,75$ & Tidak efektif \\
\hline \multicolumn{3}{c}{ Sumber: Widoyoko (2016) }
\end{tabular}

\section{Hasil penelitian}

Pengembangan sistem informasi penjadwalan mata kuliah berbasis web menggunakan model pengembangan prototyping yang terdapat pada metode pengembangan SDLC (Sistem Development Life Cycle), meliputi langkah analisis kebutuhan, perancangan, evalauasi prototype, dan produk akhir. Hasil pengembangan ini menghasilkan produk akhir yaitu sistem informasi penjadwalan mata kuliah berbasis web di Fakultas Teknik Universitas Negeri Makassar.

\section{Analisis Kebutuhan}

Pelaksanaan proses penjadwalan mata kuliah di Fakultas Teknik UNM masih dilakukan secara manual. Hasil observasi dan wawancara dengan ketua jurusan dan para staf didapat informasi proses pembuatan jadwal kuliah, informasi data dosen, dan penyebaran jadwal kuliah masih dilakukan secara manual yang memakan banyak waktu. Berdasarkan hasil observasi dan wawancara pada tanggal 6 Maret 2017 maka didapatkan beberapa data mata kuliah pada setiap jurusan di Fakultas Teknik UNM, informasi dan data yang didapat kemudian digunakan sebagai kebutuhan awal pengembangan sistem informasi penjadwalan kuliah.

\section{Perancangan}

1) Diagram Konteks

Diagram konteks dibuat menggunakan notasi-notasi untuk menggambarkan alur data dari aplikasi tanpa mempertimbangkan lingkungan fisik data tersebut, gambar diagram konteks tidak terpengaruh pada perangkat keras, perangkat lunak, struktur data.

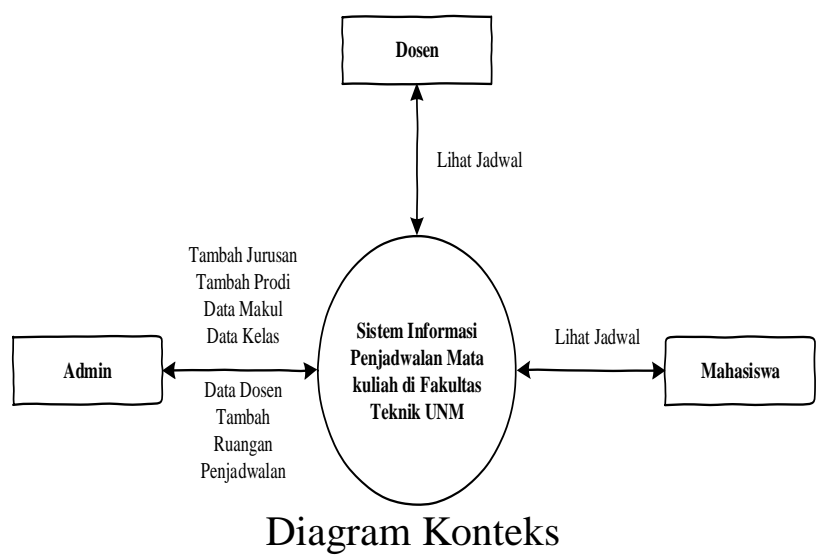




\section{2) Flowchart}

Flowchart merupakan suatu teknik untuk menyusun rencana sistem dalam bentuk simbolsimbol agar memudahkan dalam menggambarkan alur sistem. Terdapat tiga flowchart yang digunakan untuk menggambarkan alur sistem informasi, mulai dari flowchart admin, flowchart dosen, dan flowchart mahasiswa.

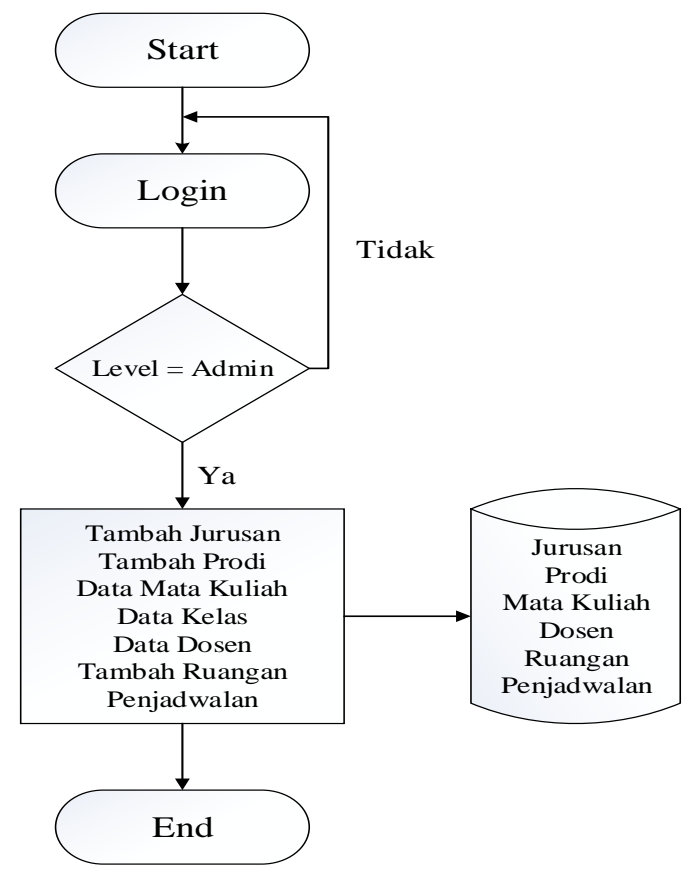

\section{Evaluasi Prototipe}

Setelah melakukan perancangan dan pembuatan prototype, selanjutnya adalah evaluasi prototype dari sistem. Evaluasi dilakukan dengan uji validasi ahli, dan uji kelompok besar.

Validasi ahli bertujuan untuk mengetahui kelayakan produk sistem informasi penjadwalan sebelum dilakukan uji coba. Validasi produk menggunakan dua validator dimana masing-masing validator mempunyai peran dalam mengevaluasi produk yang dibuat. Tahapan validasi dilakukan dengan memperlihatkan secara langsung kepada validator hasil produk yang telah dibuat, meskipun berbasis web tetapi dalam pelaksanaan validasi hanya dilakukan dengan pengujian internal yang biasa disebut dengan localhost dimana komputer sebagai server utama. Setelah melihat dan menguji produk yang ada kemudian masing-masing validator memberi komentar dan saran serta menilai produk yang telah dihasilkan.

\section{Uji Coba}

Uji coba merupakan uji coba untuk mengukur kelayakan sistem informasi penjadwalan mata kuliah yang akan digunakan dan diterapkan. Uji coba lapangan melibatkan 29 mahasiswa, 3 staf, dan 3 dosen pada Fakultas Teknik Universitas Negeri Makassar. Uji coba terdiri dari 5 indikator yaitu: (1) kualitas sistem, (2) navigasi, (3) penggunaan aplikasi, (4) kepuasan pengguna, (5) dampak bagi Fakultas Teknik Universitas Negeri Makassar. Pengujian ini dimaksudkan untuk mengukur bagaimana kualitas sistem informasi penjadwalan mata kuliah yang dihasilkan sehingga dapat diketahui kehandalan dan manfaat sistem informasi yang akan diterapkan. 


\section{Produk Akhir}

Produk akhir yang dikembangkan dalam penelitian ini adalah sistem informasi penjadwalan mata kuliah berbasis web yang dapat digunakan di lingkungan Fakultas Teknik Universitas Negeri Makassar. Sistem informasi penjadwalan mata kuliah berbasis web memberikan kemudahan dalam melakukan proses penjadwalan mata kuliah di Fakultas Teknik, memberi kemudahan dalam mengakses dan melihat jadwal mengajar dan jadwal mata kuliah secara cepat dan akurat. Tampilan produk akhir sistem informasi penjadwalan mata kuliah berbasis web dapat dilihat pada Gambar:
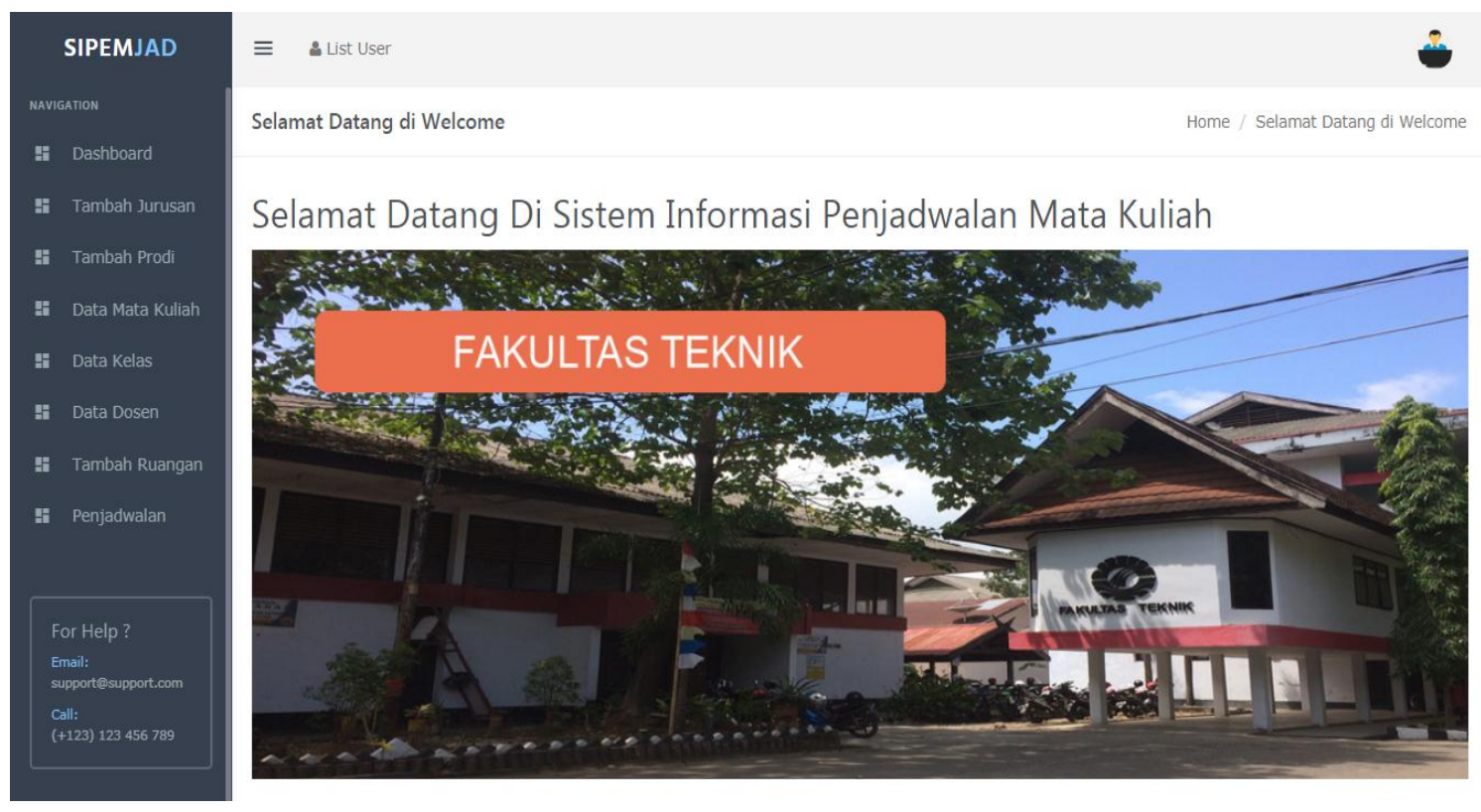

Tampilan Utama Sistem
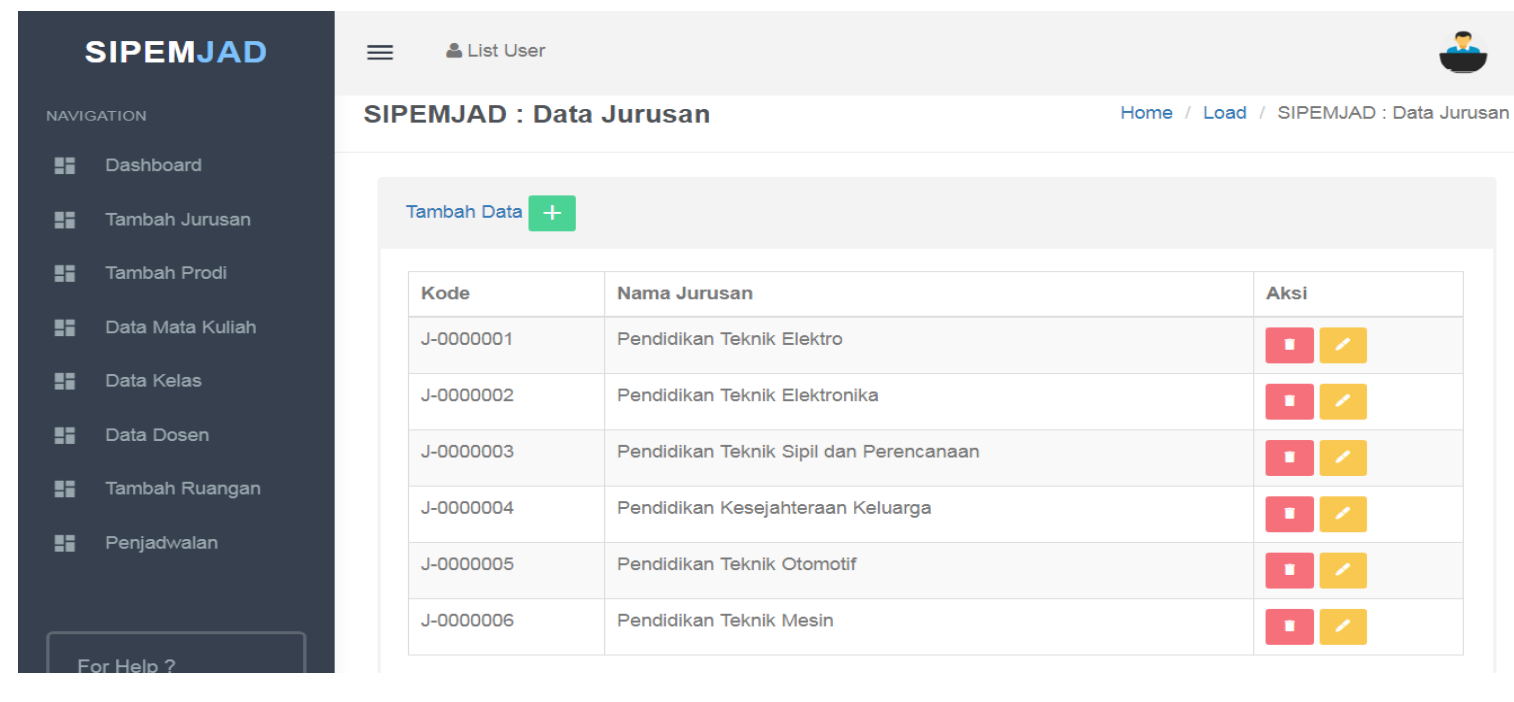

Menu Tambah Jurusan 


\section{Kesimpulan dan Saran}

\section{Kesimpulan}

1. Tahapan pengembangan sistem informasi penjadwalan mata kuliah berbasis web menggunakan metode pengembangan SDLC (Sistem Development Life Cycle) dengan model pengembangan prototype yang terdiri dari empat tahap yaitu: (1) analisis kebutuhan, (2) perancangan, (3) evaluasi prototype, (4) produk akhir. Tahap analisis kebutuhan dilakukan dengan menganalisis kebutuhan user, adapun informasi yang didapatkan dari Fakultas Teknik UNM, pelaksanaan proses pembuatan jadwal kuliah, informasi data dosen, dan penyebaran jadwal kuliah masih dilakukan secara manual yang memakan banyak waktu. Tahap perancangan terdiri dari membuat diagram konteks, data flow diagram (DFD), flowchart, dan use case diagram. Pengujian sistem dilakukan dengan pengujian kepada validasi ahli, dan uji coba lapangan.

2. Hasil penelitian menunjukkan bahwa sistem informasi penjadwalan yang dikembangkan dinyatakan valid sesuai dengan hasil validasi oleh 2 validator ahli. Hasil uji coba kepraktisan dan keefektifan sistem informasi diperoleh dari 35 responden yaitu staf, dosen, dan mahasiswa. Sistem informasi penjadwalan mata kuliah dikatakan praktis karena memenuhi kriteria kepraktisan sebuah ssistem informasi yaitu, (a) kemudahan dalam penggunaan, (b) mempersingkat waktu penyampaian informasi, dan (c) dapat menyimpan dan memperoleh informasi yang cepat, mudah, dan akurat. Berdasarkan hasil uji coba, sistem informasi pnjadwalan mata kuliah ini memperoleh kriteria sangat praktis. Sistem infromasi dikatakan efektif karena memenuhi kriteria keefektifan sebuah sitem informasi yaitu (a) kualitas sistem, (b) kualitas informasi, dan (c) kepuasan pengguna. Berdasarkan hasil dari analisis keefektifan, sistem informasi penjadwalan mata kuliah dinyatakan sangat efektif. Hal ini menunjukkan bahwa pengembangan sistem infromasi penjadwalan mata kuliah berbasis web valid, praktis, dan efektif.

\section{Saran}

1. Pada pengembangan sistem infromasi penjadwalan selanjutnya diharapkan dapat digunakan oleh seluruh pihak Fakultas Teknik Universitas Negeri Makassar.

2. Pada pengembangan sistem informasi penjadwalan diharapkan pada peneliti lain untuk mengembangkan sistem dengan metode atau bahasa pemrograman yang berbeda, seperti dikembangkan menjadi sistem yang sudah bisa melakukan penjadwalan secara otomatis, atau dikembangkan menjadi berbasis android. 


\section{DAFTAR PUSTAKA}

Abdul Kadir. 2008. Dasar Pemrograman Web Dinamis Menggunakan PHP. Yogyakarta: Andi. Abdul Kadir. 2014. Pengenalan Sistem Informasi Edisi Revisi. Yogyakarta: Andi

Adi Nugroho. 2009. Rekayasa Perangkat Lunak Menggunakan UML dan Java. Yogyakarta : Andi

DeLone, WH., dan McLean, ER. 1992. Information Systems Success: The Quest for the Dependent Variable. Information System Research, 3(1), 60-95.

Edhy Sutanta. 2003. Sistem Informasi Manajemen. Graha Ilmu. Yogyakarta.

Gupta M.P, Kanungo S, Kumar R and Sahu G.P, 2007. "A Study of Information Technology

Efectiveness in Select Government Organizations in India". Journal for Decision Makers. Vol 32. No.2.

Jogiyanto,HM. 2005. Analisis dan Desain Sistem Informasi. Yogyakarta: Andi Offset.

Jogiyanto, HM. 2009. Sistem Teknologi Informasi. Yogyakarta: Andi

La Midjan \& Susanto Azhar, 2005. Sistem Informasi Akuntansi 1. Edisi 8; Bandung: Lingga Jaya.

Nugroho, Adi. 2008. Konsep Pengembangan Sistem Basis Data. Bandung: Informatika.

O'Brien, James A.,dan George M. Marakas. 2010. Introduction to Information

Systems. New York: McGraw-Hill

Oktavian, Diar Puji. 2010. Menjadi Programmer Jempolan Menggunakan PHP.

Yogyakarta: Mediakom.

Peranginangin, Kasiman. 2006. Aplikasi WEB dengan PHP dan MySQL, Yogyakarta: Andi.

Putu Sudira. 2016. TVET ABAD XXI. Yogyakarta: UNY Press.

Richard T. Watson. 2007. Information System, Georgia.

Rosa, A.S \& M. Shalahuddin, 2013. Rekayasa Perangkat Lunak Terstruktur dan Berorientasi Objek, Bandung: Informatika.

Setialana, Wardana. 2014. Sistem Informasi Jadwal Akademik Berbasis Framework Di Jurusan Pendidikan Teknik Elektronika. Yogyakarta.

Sidik, B \& Pohan, H. I, 2009. Pemrograman Web HTML. Bandung: Informatika.

Sugiyono. 2015. Metode Penelitian \& Pengembangan (Research and Development/R\&D), Bandung: Alfabeta. 
Jurnal Pendidikan; Vol. 6, No. 2; Juli 2018. ISSN: 2337-7607; EISSN : 2337-7593 
Jurnal Pendidikan; Vol. 6, No. 2; Juli 2018. ISSN: 2337-7607; EISSN : 2337-7593 